DOI: $10.21272 /$ Ftrk.2020.12(2)-18

\title{
M. BULGAKOV AND XXth CENTURY LYTERARY PROCESS
}

\author{
Aleksieieva N. M. "The Master and Margarita» by M. Bulgakov in the Literary Context of \\ the XXth Century (Artistic Synthesis. Narrative Strategies. Mythopoetics): monograph.
} Kharkiv, 2019. 380 p.

N. S. Aleksieieva's monograph «The Master and Margarita by M. Bulgakov in the Literary Context of the 20th Century (Artistic Synthesis. Narrative Strategies. Mythopoetics)» is an integral research, devoted to a challenging issue in today's literature, that is consideration of one of the emblematic Russian literary works in comparison with the masterpieces of world literature, novels in particular.

Undertaking the research of The Master and Margarita, which has been studied across the board in great detail, the author of the monograph managed to find an original perspective and single out those aspects of Bulgakov's masterpiece, which were overlooked by modern scholars: literary synthesis, narrative aspects, mythological poetics et al. The coverage of the academic literature presented in the introduction speaks for it,

We absolutely agree with N. S. Aleksieieva about the fact that in Bukgakov's novel «there were predicted the tendencies of the development of the XX century's prose and the vectors of the formation of the world novel» (c. 9). Quiet logical seems the motivation of the choice of the novels to be compared: the same historical period (the second half on the last century), genre correlations between the novels (Lord of the Flies by W. Golding), synthetic nature of poetics (Doctor Zhivago be B. Pasternak), parabolic thinking and existential problematic ( $A$ Fable by W. Faulkner), magic realism as a common artistic method.

We approve of the author's concentration on modernism and postmodernism as on the two interrelated and interdependent stages in the literary development of the XX century, which are not only opposed to each other, but also considered like those having a lot of touch points. Factually, all this speaks for the continuity of the literary process.

According to M. Bakhtin's tenet of the modern novel as of significantly transformed in terms of structure and genre, N.S. Aleksieieva rightly defines (from the very beginning) The Master and Margarita as a polygenre formation, which incorporates the features of the myth novel, existential novel, the novel of magic realism. Here we can stress the efficiency and clarity of the formulations and the validity of the terminological pattern used.

The first chapter «The Master and Margarita: the experience of comparative studies» covers the comparative studies of Bulakov's novel with the works of letters of the XX century. The information presented demonstrate the studies available are mostly of fragmentary, nonsystematic or superficial nature. This fact speaks well for the importance and novelty of the research conducted.

In the second chapter «The Features of Mythopoetics in the Novels The Master and Margarita by M. Bulgakov and Lord of the Flies by W. Golding» includes such aspects as narrative strategies, chronotope models, infernal and eschatological motif complexes, phenomena of paradox and non-discreetness. The research shows that in both novels the authors sometimes imitate the manifestations of the mythological, prelogical consciousness. This fact is unraveled, among others, in the personification of the elements, such as fire, sun, water, air, earth. Ambivalence and open end (ending), in our view, rather witness to the romantic traditions in modernistic texts. And too categorical seems the statement that «the description of the deviant states is an attribute of methopoetics» (p. 68). By and large, the main characteristics of the both novels and the correlations between them are stated rather clearly.

The third chapter «Conceptual Synthesis and Intermediality in the Novels The Master and Margarita by M. Bulgakov and Doctor Zhivago by B. Pasternak» deals with the phenomena of literary synthesis and synthesis of arts. Conceptual synthesis here means the availability in one piece of writing both modernistic and postmodernistic elements. The 
correlations in the novels are unfolded on the background of the availability of the three artistic methods, that is realistic, modernistic and postmodern ones.

Modernistic features reveal themselves in the availability of cross-cutting motif structures, polemics with the Gospels, existential discourse etc. The author of the monograph concludes about the postmodern nature of the considered works of Bulgakov and Pasternak, featuring polyphony, internextuality, convergence of historical epochs, narratological model «text in the text», pay element, the antiquest motif, travesty, carnival poetics, dystopianism. N.S. Aleksieieva believes that M. Bakhtin's ideas of polyphony in Dostoevsky and carnivalism in Rabelais find their development in postmodern writings. As far as theatricality is concerned, Doctor Zhivago features mostly the theatre of experience, unlike Bulgakov's theatre, which resembles that of performance.

In the forth chapter «The Typology of Parabolic Thinking in the Novels The Master and Margarita by M. Bulgakov and A Fable by W. Faulkner» N.S. Aleksieieva starts from the message that parable thinking is one of the most important characteristics of the $\mathrm{XX}$ century novel, which principles are grounded in mythopoetics and existential thinking. Comparing these novels, the author of the monograph rightly comes to the conclusion that with all the cultural and mental differences the works of Bulgakov and Faulkner have concrete typological correlations.

In the first place this is the antinomies of the fictional worlds, in the second place, the system of oppositions, in the third place, the symbolization, "which postulates the creation of a large-scale, tentatively symbolic picture of the world, which, in its turn, corresponds to the universality of modern parable (p. 278).

The starting point for the comparative analysis of The Master and Margarita by Bulgakov and One Hundred Years of Solitude by G. G. Marquez (chapter 5) is the phenomenon of magic realism. The footing for that became the availability of such artistic means in both novels as carnival, oneirism, mixture of fantasy and reality, chronotope deformations etc. The research conducted shows that the representation of archetypical models in both novels has very much in common, presumably due to the fact that Marquez mostly uses the realia of European cultural tradition. Both authors employ the plots, motifs and imagery from the Bible, such as the motifs of the Lost Paradise and the Exodus, those of hurricane, crowd, Hell, the image of a beast. Universal mythologemes are presented by the mythologeme of water, the folkloric image of rooster and the modern mythologeme of train. N. S. Aleksieieva accounts all that for the long-term colonial influence Colombia and nearby countries of Latin America underwent.

Broad thinking of the author of the monograph, sophisticated approach to complicated literary texts, thorough integrity of theoretical statements place the research under consideration among the best literary studies of resent years. It is no surprise that large dimensions of the work required a lot of literary sources to be used (449 entries in Russian, Ukrainian, English et al.).

By and large, N. S. Aleksieieva's monograph is a fundamental piece of scientific discourse, possessing the topicality and perspicuous logic of academic thinking. The author demonstrates high scientific potential and levels of literary analysis, original research position. Systemic approach is successfully combined with the attention to detail, which makes the monograph of special value for modern literary scholars in the further studies.

Matsevko-Bekerska L.V

Doctor in Philology, Professor

Received: 10 September, 2020 